\title{
The Genetic Speciation of Archaeological Fish Bone: A Feasibility Study from Southeast Queensland
}

\author{
Vojtech Hlinka ${ }^{1,2}$, Sean Ulm ${ }^{3}$, Tom Loy ${ }^{1,2}$ and Jay Hall ${ }^{2}$ \\ Institute for Molecular Bioscience, University of Queensland, Brisbane, Queensland, 4072, Australia \\ School of Social Science, University of Queensland, Brisbane, Queensland, 4072, Australia \\ Aboriginal and Torres Strait Islander Studies Unit, University of Queensland, Brisbane, Queensland, 4072, Australia
}

\begin{abstract}
Current genetic methods enable highly specific identification of DNA from modern fish bone. The applicability of these methods to the identification of archaeological fish bone was investigated through a study of a sample from late Holocene southeast Queensland sites. The resultant overall success rate of $2 \%$ indicates that DNA analysis is, as yet, not feasible for identifying fish bone from any given site. Taphonomic issues influencing the potential of genetic identification methods are raised and discussed in light of this result.
\end{abstract}

\begin{abstract}
Introduction
Current methods of DNA analysis have the potential to identify archaeological fish bones to species, population or stock levels and theoretically to the individual level (Butler and Bowers 1998; Hlinka 1997, 1998; Nicholls 2000). The feasibility of applying such genetic methods to the taxonomic identification of archaeological fish bone was investigated through their application to samples from archaeological deposits in southeast Queensland. The study sample was selected from six sites in a range of depositional contexts covering different time intervals to ensure representation of a range of taphonomic conditions. For the purposes of this paper, southeast Queensland is defined as the broad bioregion extending from the Queensland-New South Wales border north to Curtis Island just north of Gladstone (Sattler and Williams 1999). The sites from which fish bone specimens were obtained include Eurimbula Site 1, Mort Creek Site Complex, Seven Mile Creek Mound, Toulkerrie, Platypus Rockshelter and Lazaret Midden (Figure 1).
\end{abstract}

\section{Sample Context \\ Eurimbula Site 1 (ES1)}

Eurimbula Site 1 is a large stratified shell midden complex intermittently exposed for some $2 \mathrm{~km}$ along a steep erosion face of the western bank of Round Hill Creek on the eastern margin of Eurimbula National Park (Ulm et al. 1999). Exploratory excavation was carried out at 10 loci in the complex (total $3.25 \mathrm{~m}^{2}$ ). The matrix varied from light brown-grey or brown-yellow sand to dark brown humic soil and its $\mathrm{pH}$ was $6.0-7.0$, with the highest values towards the base of the deposit. Ten radiocarbon dates indicate occupation over the past 3,000 years (Ulm and Reid 2000). The recovered cultural material includes shellfish remains dominated by mud ark (Anadara trapezia) and oyster (Saccostrea glomerata), stone artefacts and small quantities of fish bone. Square A yielded 301 fish bone fragments weighing $5.59 \mathrm{~g}$ in total $(\mathrm{NISP}=2 ; \mathrm{MNI}=2$ ) (Vale 2002). Bream (Acanthopagrus australis) and other sparid (Sparidae family) remains have been tentatively identified on morphological grounds. As humic material had discoloured most of these fish bones, the least discoloured specimens were selected for analysis.

\section{Mort Creek Site Complex (MCSC)}

The Mort Creek Site Complex is on the west bank of Mort Creek, on the west coast of Rodds Peninsula in Eurimbula National Park (Carter et al. 1999). Natural and cultural shell deposits extend discontinuously over an area of about 6ha and are associated with a stone-walled tidal fish trap. Limited excavations were undertaken in four separate areas (total $1.75 \mathrm{~m}^{2}$ ). Excavation of shell midden deposits revealed quantities of shellfish remains dominated by mud ark (Anadara trapezia), with lesser quantities of hercules club whelk (Pyrazus ebininus) and oyster (Saccostrea glomerata). Numerous fish vertebrae were recovered along with turtle carapace fragments and stone artefacts. Twelve radiocarbon indicate first occupation shortly before c. 3,300 cal BP and apparent abandonment about 1,900 years ago (Ulm and Reid 2000). Sediments were gently dry sieved through $3 \mathrm{~mm}$ mesh and material from Squares C and D was manually sorted prior to wet sieving in order to remove fish vertebral components for DNA analysis. Site $\mathrm{pH}$ for the analysed squares was 7.0-8.0. Square C yielded 1,020 fish bone fragments weighing $26.38 \mathrm{~g}$ in total (NISP=29; $\mathrm{MNI}=17$ ), most of which were vertebral fragments and humic material and carbonisation (from burning) had discoloured most of these (Vale 2002). Attempts at morphological identification resulted in only a few specimens being tentatively labelled as bream (Acanthopagrus australis), squire (Chrysophrys auratus), whiting (Sillago sp.) and catfish (Arius sp.).

\section{Seven Mile Creek Mound (SMCM)}

The Seven Mile Creek Mound lies on a low residual beach ridge fringing Seven Mile Creek, a tributary of Rodds Harbour (Ulm 2002). This discrete mound is some $20 \mathrm{~m}$ long, $10 \mathrm{~m}$ wide and $0.8 \mathrm{~m}$ deep. A single $1 \mathrm{~m} \times 1 \mathrm{~m}$ pit (Squares A-D) dug into the highest part of the mound revealed an $85 \mathrm{~cm}$ unit of dense shell resting on wellrounded beach sands containing occasional pieces of shell and degraded pumice. Shellfish remains, including oyster (Saccostrea glomerata), mud ark (Anadara trapezia), hairy mussel (Trichomya hirsuta), hercules club whelk (Pyrazus ebeninus) and lined nerite (Nerita lineata), dominated the deposit. Mud crab (Scylla serrata) shell was also common. Fish bone and stone artefacts were observed throughout the 
deposit. The $\mathrm{pH}$ of Square A varied between 8.0 and10.0+, with the lower values recorded at the base of the deposit below the dense shell layer. Eight radiocarbon determinations indicate first occupation around c.3,900 cal BP and abandonment shortly after c.3,600 cal BP (Ulm 2002). This mound thus provides some of the earliest evidence of highly focussed marine resource exploitation from an open archaeological deposit on the Queensland coast. After gentle dry screening through $3 \mathrm{~mm}$ mesh, fish remains were manually collected and bagged for identification and DNA analysis. A total of 1,346 fish bone fragments weighing $34.39 \mathrm{~g}$ were recovered (NISP=54; MNI=37), among which Platycephalidae, Sillaginidae and Sparidae were identified on the basis morphological characteristics (Vale 2002).

\section{Toulkerrie}

Toulkerrie is an extensive midden complex on low sand ridges on the southwest coast of Moreton Island (Hall 1984; Hall and Bowen 1989; Walters 1986). Bream (Acanthopagrus australis), tarwhine (Rhabdosargus sarba), snapper (Chrysophrys auratus), mullet (Mugil cephalus) and whiting (Sillago sp.) dominate the vertebrate component of the faunal assemblage. Walters (1986:189193) excavated $10 \mathrm{small}(50 \mathrm{~cm} \times 50 \mathrm{~cm})$ pits adjacent to Hall's original Trench 6. All material was wet sieved through $3 \mathrm{~mm}$ mesh. Several specimens were originally selected for seasonal ring pattern studies and they were catalogued and numbered (I. Walters, School of Humanities and Social Sciences, Northern Territory University, pers. comm., 2000). Although the catalogue has since been lost, the 'catalogued' fish bones are still identifiable morphologically, making the specimens ideal for correlating genetic with morphological results. Mullet vertebrae were selected for DNA analysis because they dominate the catalogued samples and vary in physical appearance. For example, colour differences reflect different local taphonomic conditions affecting each bone (e.g. the degree of burning). One whiting bone was also selected from an uncatalogued sample.

\section{Platypus Rockshelter}

Platypus Rockshelter is an inland site within a weathered cavity in a conglomerate cliff on the Brisbane River near Fernvale. The deposits are divided into seven main stratigraphic units based on colour, texture and content and the occupation sequence spans the past 5,300 years or so (Hall et al. 1988). The matrix varies from pebbly, stony or sandy silt-clay to weakly stratified dry ashy soil and $\mathrm{pH}$ varies from 6.0 to 8.5 (Hall et al. 1988:29-31). Distinctive signs of burning include abundant ash and charcoal as well as the discolouration of some sediments (e.g. in SU7 the normally yellowish brown deposit is discoloured to reddish brown presumably from burning in SU6 above) (Hall et al. 1988:29-31). The location and morphology of the rockshelter protected the deposits against water and vegetation growth and some of the bone was further protected by a reddish silt-clay cover, making such specimens potentially ideal for DNA analysis. Fish remains, including sea mullet and catfish, were discarded at Platypus Rockshelter as early as 4,200 BP (Novello 1989). Two catfish vertebrae and fish plate fragments were selected for analysis.

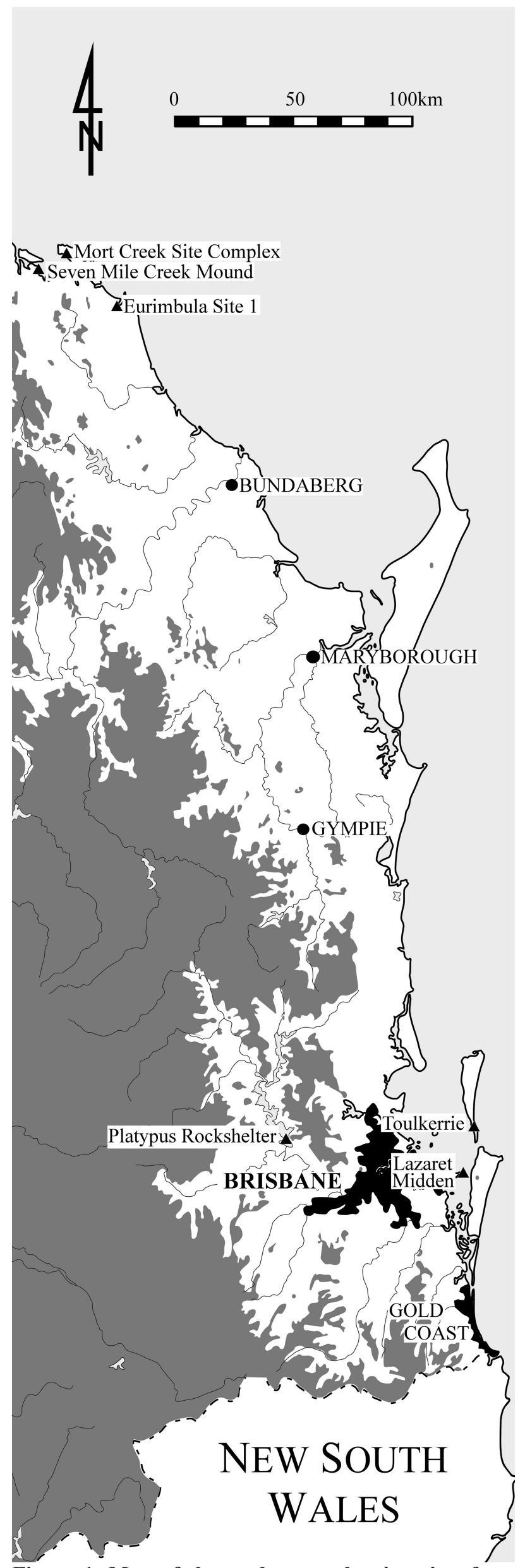

Figure 1. Map of the study area showing sites from which samples were selected. 


\section{Lazaret Midden}

The Lazaret Midden is located on the northeast margin of Peel Island in Moreton Bay. Ross and members of the Quandamooka Cultural Resources Management Team excavated four $50 \mathrm{~cm} \times 50 \mathrm{~cm}$ test pits in three locations across the deposits (Ross and Duffy 2000). Material was sieved through $6 \mathrm{~mm}, 3 \mathrm{~mm}$ and $1 \mathrm{~mm}$ mesh. Two of these pits have been analysed, although full results are yet to be published. The age of the deposit ranges from c. 1,200 cal BP at the base to modern at the top (A. Ross, School of Social Science, University of Queensland, pers. comm., 2002). A piece of burnt spine recovered by dry sieving was supplied to determine if DNA could be retrieved from such a small fragment $(2.7 \mathrm{mg})$. It came from XU12 in Pit A, making it older than the c. 600 cal BP age obtained for XU10. Burning has affected most specimens from this site.

\section{DNA-Based Identification}

Mitochondrial DNA (mtDNA) is found in cell cytoplasm outside the nucleus where nuclear DNA is contained (Dorit et al. 1991:46). By studying the sequence of the four bases of DNA and changes in the bases within regions with high variation such as the $16 \mathrm{~S}$ rRNA gene (16S mtDNA), one can identify samples to the family, species or population level, including bones difficult or impossible to identify on the basis of gross morphology. Although 16S mtDNA cannot resolve between some related species, the region is particularly useful within a bounded geographical context where the number of related species is limited. Other target regions, such as the D-loop region, can be used for higher taxonomic resolution if necessary.

The first step in the analysis is to obtain reference sequences from species that inhabited the study region in the past. A number of useful sequences, including those from related species sharing similar sequences to those under study, can be found on World Wide Web databases such as EMBL or GenBank, while others may have to be added by the researcher. Compared to morphological collections, these web databases have the advantages of being readily available, easily accessed and cheaper to establish and maintain. Once unknown samples are aligned to those in the database, it is possible to match and identify the sequences. A sequence database of several species, either present in the region or closely related to them, has been established for southeast Queensland (Hlinka in prep.). This database consists of a section of domain V $16 \mathrm{~S}$ mtDNA that has been found useful in identifying both modern and archaeological fish remains (Hlinka 1998; Nicholls 2000). We recognise that this database represents only a fraction of the species expected in archaeological deposits in the study area and we hope that researchers can add to it as work in this field progresses. After all, DNA research into archaeological fish material is relatively new; publication of results began with Crockford (1996) and was closely followed by Hlinka (1997, 1998), Butler and Bowers (1998), Nicholls (2000) and van Neer et al. (2000).

\section{Methods}

One of the main problems with DNA analysis of archaeological fish bone is that the bones of most of the higher teleosts are acellular; that is, they lack cells called osteocytes in the mineral matrix. Usually this type of bone will also lack other cell types (Moss 1963; Norris et al.
1963; Ruben and Bennett 1981, 1987; Urist 1964), although this is not always the case (Hughes et al. 1994; Sire et al. 1990). Acellularity was first researched in the nineteenth century by Kölliker (1859) and subsequently by others (e.g. Enlow and Brown 1956; Moss 1961; Hall 1978; Ekanayake and Hall 1988). In most acellular bone the DNA-containing cells are largely present in the outer and inner surfaces of the bone (Ekanayake and Hall 1988). A standard method in the preparation of archaeological samples is to remove or irradiate the outer surface in order to cross-link potential contaminating DNA and prevent it from participating in the Polymerase Chain Reaction (Hummel and Herrmann 1994). Unfortunately, this step removes DNA from completely acellular fish bone. Because each unidentified bone should be treated as potentially acellular, the samples in this study were not UV irradiated or chemically treated prior to analysis.

As DNA analysis requires destruction of the sample, a thorough metrical and photographic record was made of all specimens in this study prior to analysis. Samples selected from the six archaeological sites were powdered either prior to extracting DNA or during the extraction process. DNA was extracted either with a Potassium or NaAcetate buffer (Hlinka 1997) or the GuSCN buffer (Boom et al. 1990). It was subsequently purified using either GuSCN (Boom et al. 1990) or the NaI binding buffer (Boom et al. 1990; Hlinka 1997; Loy 1993), using silica to bind DNA and remove proteins and other compounds. Chloroform separation and further purification through Millipore $100,000 \mathrm{kDa}$ filters were undertaken to remove PCR inhibitors that sometimes co-elute with the purified DNA.

The primers utilised in this study are presented in Table 1. Modern samples that were sequenced were amplified either with primers $16 \mathrm{SVHF}$ and $16 \mathrm{SVHR}$ or primers 16 S2VHF and 16SVHR. DNA from archaeological samples was typically amplified, purified, reamplified and repurified prior to sequencing. Table 2 presents the primer combinations used for the archaeological samples.

The most effective primer set is the last one listed, a fact determined from successful amplifications from 9,000 year old bones from Cyclops' Cave, Youra, Greece. The PCR employs one primer combined with a PEP primer in a method called genomic walking. It targets a final product of approximately 100 base pairs in length. The products were sequenced using the BigDye Terminator mix using the optimal PCR conditions for the relevant primers. For sequencing archaeological PCR products, 16S2VHF and FishCf were typically used, while 16 S2VHF, 16SVHF or $16 \mathrm{SVHR}$ were used for sequencing the modern samples.

Table 1. Primers used in this study.

\begin{tabular}{|l|l|}
\hline FishCf & TGTCTTTGGTTGGGGCGACC \\
\hline 16 SVHF & GAGAAGACCCTATGGAGCTT \\
\hline 16 S2VHF & AGACCCTATGGAGCTTTAGA \\
\hline 16 SVHR & GATCCAACATCGAGGTCGTA \\
\hline RFCf & TGGTCGCCCCAACCGAA \\
\hline PEP & NNNNNNNNNNNNNNNNNNNN \\
\hline
\end{tabular}


Table 2. Primer combinations used for archaeological samples.

\begin{tabular}{|l|l|l|}
\hline \multicolumn{1}{|c|}{ Initial Primers } & \multicolumn{1}{c|}{ Procedure } & \multicolumn{1}{c|}{ Secondary Primers } \\
\hline 16S2VHF and 16SVHR & followed by purification and reamplification with & FishCf and 16SVHR \\
\hline 16S2VHF and 16SVHR & followed by purification and reamplification with & 16S2VHF and RFCf \\
\hline FishCf and PEP & followed by purification and reamplification with & FishCf and 16SVHR \\
\hline 16S2VHF and PEP & followed by purification and reamplification with & 16S2VHF and 16SVHR \\
\hline 16S2VHF and PEP & followed by purification and reamplification with & 16S2VHF and RFCf \\
\hline
\end{tabular}

\section{Results}

Seven of 51 extracts produced a PCR product, albeit one of these was a false positive. In the case of the false positive, the waterblank negative control was also positive. The contaminant source was traced to a positive control that was used during the optimisation of the genetic methods. As a result only six extracts gave true positive amplification products. A success rate of $12 \%$ was obtained for amplification. Most of these products were not cleanly amplified and were barely detectable when run on 4-20\% gradient polyacrylamide gels from BioRad. Only one of the six extracts sequenced produced a product; this was the Toulkerrie mullet specimen (\#2278) which resulted in a sequence that did not match any of those in the reference database. In sum, the overall success rate to the sequencing stage was only $2 \%$.

Table 3 documents relevant details concerning the samples analysed. It is evident that the sample source varied in terms of site location and depth and that it represents a range of microenvironments and taphonomic conditions. In general, most of the results were negative, with specimens from Platypus Rockshelter recording the highest success rate $(50 \%)$ for amplification products. As all the different genetic methods utilising the listed extraction and purification buffers gave mostly negative results, there appears to be no obvious correlation between method and result. Also, there is clearly no correlation between the weight of the bone specimen analysed and amplification success. Even different sections of the same element can produce varying results, as the fish plate from Platypus Rockshelter indicates.

\section{Discussion}

This result of an overall success rate of $2 \%$ far from demonstrates the feasibility of the application of these genetic methods to fish bones from any given archaeological site. However, an examination of samples that gave a PCR product provides some understanding of the issues associated with amplifying DNA from archaeological fish bone. For one thing, we suggest that the type of bone as well as its taphonomic and diagenetic history play an influential role in the amplification success rate. Secondly, specimens from particular sites appear to yield a higher amplification success rate than those from other sites. In the case of Platypus Rockshelter a coating of clay appears to have protected the DNA as did the very nature of the site matrix itself; further, the impacts of vegetation, humic acids, oxidation and moisture were minimal. On the other hand, the other sites were more open and exposed to sunlight, vegetation and water penetration. Such exposure to the elements appears to be particularly important to the preservation of DNA in fish bone. Nicholls (2000:77) found that samples from exposed localities of the open Moturakau site 'exhibited substantially lower genetic yields' than those adjacent to or completely inside rockshelters. This result contrasted with a $100 \%$ success rate obtained from mainland samples recovered from either sand or loamy sand matrices (Nicholls 2000). Similarly, Hlinka (in prep.) has successfully sequenced cranial samples from Cyclops' Cave.

There are two reasons why DNA from fish bones may fail to amplify. One is the carryover of PCR inhibitors during purification that will stop the amplification process - a problem that was encountered with the archaeological fish bone. Butler and Bowers (1998:25) dealt with this problem by using hexadecyltrimethyl-ammonium bromide (CTAB), a detergent used to eliminate carbohydrates, phenolics and other contaminants. In our study the addition of a prewash, chloroform separation and final filtration step to remove all traces of inhibitors further enhanced this purification process. The second reason for failure is the physical condition of the DNA within the bones; it may have been damaged not only by environmental agents but by the effects of food preparation techniques such as frying, boiling and burning. While frying and boiling are pre-discard activities, burning can affect DNA before, during and after discard. Nicholls (2000) found that DNA could still be analysed from bone samples that had been boiled for three hours and believes this form of heating may not significantly alter the integrity of DNA present.

As burning or charring is a common attribute exhibited by the southeast Queensland samples (Walters 1986:240), the effect of burning needs to be studied in more detail. Bones can be burnt or charred not only through cooking but also after deposition (e.g. from fires in sedimentary units above). Recent experiments indicate that the DNA from the outer layer is particularly susceptible to fire damage (Hlinka in prep.). For burnt bone in particular, given the small amount of DNA that may remain, it is necessary to use the entire bone for extraction and purification. A low intensity fire (up to $450-500^{\circ} \mathrm{C}$ ) of four minute's duration carbonises the surface and the adjacent subsurface section with no calcination (David 1990). In a controlled experiment, a mackerel bone was burnt for two minutes over leaf and fine twig matter (spinifex and dry grasses) with the temperature expected to range from 600-1, $000^{\circ} \mathrm{C}$ (David 1990:67). No product could be amplified from the carbonised outer layer. 
Table 3. Summary of DNA analysis results from the archaeological fish bone sample.

\begin{tabular}{|c|c|c|c|c|c|c|c|}
\hline Site & $\begin{array}{c}\text { Sample } \\
\#\end{array}$ & Element & $\begin{array}{c}\text { Morphological } \\
\text { ID }\end{array}$ & $\begin{array}{c}\text { Weight } \\
\text { (mg) }\end{array}$ & $\begin{array}{c}\text { Weight } \\
\text { Analysed } \\
\text { (mg) }\end{array}$ & Buffers & $\begin{array}{c}\text { Fish-like } \\
\text { PCR } \\
\text { Product }\end{array}$ \\
\hline SMCM & $5 \_9$ & Proatlas vertebra & Unidentified & 49.0 & 49.0 & GuSCN/GuSCN & Negative \\
\hline SMCM & $12 \_1$ & Atlas vertebra & Unidentified & 57.8 & 57.8 & GuSCN/GuSCN & Negative \\
\hline SMCM & $14 \_2$ & Precaudal vertebra & Unidentified & 47.4 & 47.4 & GuSCN/GuSCN & Positive \\
\hline SMCM & $15 \_5$ & Precaudal vertebra & Unidentified & 17.6 & 17.6 & GuSCN/GuSCN & Negative \\
\hline SMCM & $15 \_16$ & Precaudal vertebra & Unidentified & 24.5 & 24.5 & GuSCN/GuSCN & Negative \\
\hline SMCM & $25 \_1$ & Atlas vertebra & Unidentified & 44.5 & 44.5 & GuSCN/GuSCN & Negative \\
\hline Platypus & 1 & Vertebra & Catfish & 42.0 & 42.0 & GuSCN/GuSCN & Negative \\
\hline Platypus & 2 & Vertebra & Catfish & 34.6 & 34.6 & GuSCN/GuSCN & Positive \\
\hline Platypus & 3 & Fish plate & Unidentified & 788.3 & 134.0 & GuSCN/GuSCN & Positive \\
\hline Platypus & 3 & Fish plate & Unidentified & 788.3 & 103.0 & NaAcetate/GuSCN & Negative \\
\hline ES1 & $5 \_1$ & Vertebra & Unidentified & 26.8 & 26.8 & GuSCN/GuSCN & Negative \\
\hline ES1 & $6 \_1$ & Atlas vertebra & Sparidae & 13.4 & 13.4 & GuSCN/GuSCN & Negative \\
\hline ES1 & $6 \_2$ & Vertebra & Unidentified & 31.1 & 31.1 & GuSCN/GuSCN & Negative \\
\hline ES1 & $8 \_1$ & Basioccipital & Unidentified & 24.9 & 24.9 & GuSCN/GuSCN & Negative \\
\hline ES1 & $8 \_2$ & Atlas vertebra & Silver Bream & 15.0 & 15.0 & GuSCN/GuSCN & Negative \\
\hline ES1 & $12 \_1$ & Vertebra & Unidentified & 132.1 & 73.2 & GuSCN/GuSCN & Negative \\
\hline ES1 & $12 \_1$ & Vertebra & Unidentified & 132.1 & 56.5 & NaAcetate/GuSCN & Negative \\
\hline $\mathrm{ES} 1$ & $14 \_1$ & Vertebra & Unidentified & 37.1 & 37.1 & GuSCN/GuSCN & Negative \\
\hline MCSC & $4 \_2$ & Vertebra & Unidentified & 19.7 & 19.7 & $\mathrm{KCOOH} / \mathrm{NaI}$ & Negative \\
\hline MCSC & $6 \_5$ & Vertebra & Unidentified & 32.0 & $\sim 30.0$ & $\mathrm{KCOOH} / \mathrm{NaI}$ & Negative \\
\hline MCSC & 6_9 & Vertebra & Whiting & 46.0 & 35.4 & $\mathrm{KCOOH} / \mathrm{NaI}$ & Negative \\
\hline MCSC & 6_9 & Vertebra & Whiting & 46.0 & 10.6 & $\mathrm{KCOOH} / \mathrm{NaI}$ & Negative \\
\hline MCSC & 7_9 & Vertebra & Squire & 32.3 & $\sim 7.3$ & $\mathrm{KCOOH} / \mathrm{NaI}$ & Negative \\
\hline MCSC & 7_9 & Vertebra & Squire & 32.3 & $\sim 25.0$ & $\mathrm{KCOOH} / \mathrm{NaI}$ & Negative \\
\hline MCSC & $7 \_10$ & Vertebra & Unidentified & 43.0 & 24.0 & $\mathrm{KCOOH} / \mathrm{NaI}$ & Negative \\
\hline MCSC & $7 \_12$ & Vertebra & Unidentified & 106.2 & 88.8 & $\mathrm{KCOOH} / \mathrm{NaI}$ & Negative \\
\hline MCSC & $7 \_13$ & Vertebra & Unidentified & 80.7 & 20.2 & NaAcetate/NaI & Negative \\
\hline MCSC & $7 \_13$ & Vertebra & Unidentified & 80.7 & 60.5 & $\mathrm{KCOOH} / \mathrm{NaI}$ & Negative \\
\hline MCSC & $8 \_5$ & Vertebra & Squire & 27.2 & 17.6 & $\mathrm{KCOOH} / \mathrm{NaI}$ & Negative \\
\hline MCSC & $8 \_7$ & Vertebra & Silver Bream & 20.8 & 20.8 & $\mathrm{KCOOH} / \mathrm{NaI}$ & Negative \\
\hline MCSC & $8 \_15$ & Vertebra & Unidentified & 9.4 & 9.4 & $\mathrm{KCOOH} / \mathrm{NaI}$ & Negative \\
\hline MCSC & 8_19 & Vertebra & Silver Bream & 20.6 & 20.6 & $\mathrm{KCOOH} / \mathrm{NaI}$ & Negative \\
\hline MCSC & $8 \_20$ & Thoracic vertebra & Catfish & 19.7 & 19.7 & $\mathrm{KCOOH} / \mathrm{NaI}$ & Negative \\
\hline MCSC & $5 \_3$ & Vertebra & Silver Bream & 216.2 & 216.2 & GuSCN/GuSCN & Positive \\
\hline
\end{tabular}


Table 3. Summary of DNA analysis results from the archaeological fish bone sample (cont.).

\begin{tabular}{|c|c|c|c|c|c|c|c|}
\hline Site & $\begin{array}{c}\text { Sample } \\
\#\end{array}$ & Element & $\begin{array}{c}\text { Morphological } \\
\text { ID }\end{array}$ & $\begin{array}{c}\text { Weight } \\
\text { (mg) }\end{array}$ & $\begin{array}{c}\text { Weight } \\
\text { Analysed } \\
\text { (mg) }\end{array}$ & Buffers & $\begin{array}{c}\text { Fish-like } \\
\text { PCR } \\
\text { Product }\end{array}$ \\
\hline Lazaret & 12 & Spine & Unidentified & 2.7 & 2.7 & $\mathrm{KCOOH} / \mathrm{NaI}$ & Negative \\
\hline Toulkerrie & 198 & Vertebra & Mullet & 51.4 & 51.4 & $\mathrm{KCOOH} / \mathrm{NaI}$ & Negative \\
\hline Toulkerrie & 304 & Vertebra & Mullet & 47.5 & 47.5 & $\mathrm{KCOOH} / \mathrm{NaI}$ & Positive \\
\hline Toulkerrie & 2116 & Vertebra & Mullet & 34.4 & 34.4 & $\mathrm{KCOOH} / \mathrm{NaI}$ & Negative \\
\hline Toulkerrie & 2165 & Vertebra & Mullet & 107.7 & 38.0 & $\mathrm{KCOOH} / \mathrm{NaI}$ & Negative \\
\hline Toulkerrie & 2165 & Vertebra & Mullet & 107.7 & 52.1 & $\mathrm{GuSCN} / \mathrm{NaI}$ & Negative \\
\hline Toulkerrie & 2173 & Vertebra & Mullet & 136.7 & 68.4 & $\mathrm{GuSCN} / \mathrm{NaI}$ & Negative \\
\hline Toulkerrie & 2173 & Vertebra & Mullet & 136.7 & 54.4 & $\mathrm{KCOOH} / \mathrm{NaI}$ & Negative \\
\hline Toulkerrie & 2193 & Vertebra & Mullet & 56.0 & 56.0 & $\mathrm{KCOOH} / \mathrm{NaI}$ & Negative \\
\hline Toulkerrie & 2269 & Vertebra & Mullet & 162.5 & 162.5 & $\mathrm{KCOOH} / \mathrm{NaI}$ & Negative \\
\hline Toulkerrie & 2278 & Vertebra & Mullet & - & 12.0 & $\mathrm{KCOOH} / \mathrm{NaI}$ & Positive \\
\hline Toulkerrie & 2349 & Vertebra & Mullet & 74.9 & 74.9 & $\mathrm{KCOOH} / \mathrm{NaI}$ & Negative \\
\hline Toulkerrie & 4040 & Vertebra & Mullet & 67.4 & 67.4 & $\mathrm{KCOOH} / \mathrm{NaI}$ & Negative \\
\hline Toulkerrie & 4063 & Vertebra & Mullet & 67.8 & 67.8 & $\mathrm{KCOOH} / \mathrm{NaI}$ & Negative \\
\hline Toulkerrie & 4067 & Vertebra & Mullet & 35.9 & 35.9 & $\mathrm{KCOOH} / \mathrm{NaI}$ & Negative \\
\hline Toulkerrie & 4869 & Vertebra & Mullet & 90.3 & 90.3 & $\mathrm{KCOOH} / \mathrm{NaI}$ & Negative \\
\hline Toulkerrie & 2041 on & Vertebra & Whiting & 52.8 & 52.8 & $\mathrm{GuSCN} / \mathrm{NaI}$ & False positive \\
\hline
\end{tabular}

Clearly, the survival of DNA can be expected to be greater in larger bones where it is better protected. According to one hypothesis, based on the idea that microbial activity plays a role in breaking down ancient DNA in bone, destruction of the bulk of organic material from bones by burning (cremation) may prevent subsequent bacterial colonisation 'by removing possible nutrients, thereby providing an environment that is conducive to survival of DNA remains' (Brown et al. 1995:186). This situation would aid the survival of DNA present below the carbonised outer layer. An alternative hypothesis is that burning frees up nutrients to plants and therefore allows parts of the bone to become exposed to plant root penetration, thus exposing the DNA to microbial and chemical damage. Either way, microbes may be expected to play a significant role in the breakdown of DNA from burnt bone in the early stages of burial. Nicholls (2000) also considered bone mass as a factor influencing the survival of DNA but found no strong relationship between size and successful extraction. Certainly, no strong relationship between size and extraction success obtains for the southeast Queensland material.

While the typical size of denatured DNA is about 200 base pairs (Kelman and Moran 1996), this number can vary due to different diagenetic histories. With archaeological fish bone DNA fragments, preservation sizes of approximately 100-120 base pairs in length or less appear more common. Butler and Bowers (1998) were able to amplify DNA 120 base pairs in size but were unsuccessful in amplifying sequences between 209 and 231 base pairs in length. Of the four samples analysed with the 119 base pair primers, only one produced a reliable sequencing result, a 12-20 year old vertebra which was surface collected. The DNA template from this relatively modern sample may have been of a higher quality than that from the 500 and 9,000 year old specimens analysed, thus resulting in lower PCR artefact formation. A dentary of similar age (12-20 years) produced an unreliable sequence. Nicholls (2000) utilised a 100 base pair section of domain V 16S mtDNA which yielded sequences for 21 useful sequences out of 29 samples. Eighteen of the successful samples came from the Moturakau site and three were from Ureia, both on the island of Aitutaki in the southern Cook Islands. The most successful results from our laboratory also came when shorter targets of approximately 100 base pairs were targeted for archaeological samples from Cyclops' Cave. Although we utilised the same 100 base pair section of domain V 16S mtDNA as did Nicholls, this strategy was not very successful for the amplification of the southeast Queensland samples. Arndt, van Neer, Volckaert and Waelkens also found that different short targets in the Dloop region amplified with different success rates when working on archaeological catfish samples (van Neer, Royal Museum of Central Africa, Belgium, pers. comm., 
2001). Van Neer and colleagues also found the shortest target having the greatest success rate. The degree of DNA fragmentation in our Queensland study, specifically for the domain V 16S mtDNA region, typically appears to be lower than the 100 base pair threshold.

The evaluation of the base pair preservation threshold from one DNA target, such as a part of the domain V 16S, is an approximate evaluation that may not necessarily be extended to represent the general base pair preservation encountered from an individual sample. Due to the differential preservation of different targets, the base pair preservation threshold varies for different sections of DNA. We have found differences in the success rates when amplifying DNA from different regions approximately 100 base pairs in size or less when working on archaeological fish bone samples from Cyclops' Cave.

Different skeletal elements appear to also have different success rates. The highly successful studies by Nicholls (2000) and Hlinka (in prep.) have been primarily on cranial elements. The pilot study by Nicholls (2000) noted the best results for cranial elements and a poor result for vertebrae; also, maxillae had a $100 \%$ success rate while premaxillae had a $64 \%$ success rate. Hlinka (in prep.) found that cranial elements from Cyclops' Cave produced an equally high success rate, whereas most vertebral elements from the southeast Queensland sample yielded low success rates. This study found that even different sections of the same element can produce negative and positive results. The type of skeletal element, structure of the bone and sampling are obviously key elements that contribute to the relative success of a result.

Evidence suggests that sediment $\mathrm{pH}$ also influences the survival of DNA in fish bone. In a laboratory experiment, mullet, whiting and silver bream vertebrae were immersed in Tris- $\mathrm{HCl}$ solutions at different $\mathrm{pH}$ (ranging from 4-10) for periods of six months for mullet and nine months for whiting and silver bream. After extraction and purification, the greatest amount of PCR product was obtained from samples at $\mathrm{pH} 4-6$ and $\mathrm{pH} 10$ while a range of 7-9 resulted in the least amount. This result may be due to the fact that DNAses and other proteins are most active in a neutral environment and result in a greater destruction of the DNA. Also interesting is that acidic conditions, while not useful for the preservation of the bone, may result in the survival of DNA. It might be useful to apply these methods to test sediments from sites where fish bones are not actually present but for which fish discard might be expected (e.g. coastal middens).

Although certain types of contamination can be avoided, the greatest threat comes from the DNA of other fish. It is generally assumed that little DNA transfer occurs within soils at archaeological sites; however, this assumption has not been investigated until recently (Hlinka in prep.). At sites where there is movement of soil components or contact between different parts of fish, a potential problem with DNA transfer exists. In association with this question is the need to study how DNA is transferred when several fish are buried together. Whether certain types of bones such as the more exposed premaxillae are more subject to contamination than protected bones such as vertebrae, remains to be investigated. Research based on the Cyclops' Cave samples strongly suggests that taphonomic processes play a significant role in the transfer of DNA from one fish to another (Hlinka in prep.). This outcome means that different levels of confidence in genetic fish bone identification need to be established for each site. Morphologically identified samples must be analysed genetically for each site before analysing unidentified samples to determine whether or not the genetic identification results are statistically representative. The unidentified sequence from the Toulkerrie mullet (\#2278) is considered a result of DNA transfer due to taphonomic factors. Resettling and remixing soils containing DNA also has the potential to increase the cross-contamination of fish bones.

Another potential for fish DNA transfer comes from handling the remains during and after excavation. Such contamination related to recovery and analysis can be minimised by taking appropriate precautions, such as bagging fish bones separately, handling samples with sterile tweezers and exposing samples as little as possible. Wet sieving may increase the likelihood of bone surfaces being contaminated with exotic DNA from soils or other bones; however, this problem can be largely circumvented by avoiding sieving altogether or by dry sieving.

\section{Conclusion}

We suggest an alternative approach to sequencing for archaeological fish bone speciation by determining the presence or absence of short fragments of DNA amplified from archaeological samples rather than relying on sequence analysis. For speciation, sets of highly specific primers could be developed for common species and the PCR can be run as a multiplex (i.e. with multiple primers used in a single amplification). In this way, if working with vertebrae for example, the rate for a successful result would increase given that the amplification success rate is greater $(12 \%)$ than the sequencing success rate $(2 \%)$ in the southeast Queensland samples.

We stress that the application of genetic methods to archaeological fish bone identification must be undertaken with great caution. Its feasibility depends on various factors associated with the types of specimens collected and their history; taphonomy and diagenesis play a major role in the preservation and location of DNA in archaeological fish bone. As it can no longer be assumed that DNA analysed from a specific fish bone represents the original DNA, the application of genetic methods is not warranted in sites where the statistical level of correct genetic identification is low. However, where confidence levels are high and the research question warrants the associated expense, genetic methods may be useful, especially if fish species are targeted using highly specific primer sets.

\section{Acknowledgements}

We thank members of the Gooreng Gooreng community and the Gurang Land Council Aboriginal Corporation for allowing and facilitating the study the fish bones from Eurimbula Site 1, Mort Creek Site Complex and the Seven Mile Creek Mound. Analyses of samples from these sites were funded by an Australian Institute of Aboriginal and Torres Strait Islander Studies Research Grant (\#G99/6224) to Hlinka. We also thank Dr Anne Ross (University of Queensland) for providing the Lazaret Midden sample for this study. Tony Eales helped prepare Figure 1. We thank Deborah Vale (University of New England) and Victoria Francis (University of Queensland) for comments and advice. 


\section{References}

Boom, R., C.J.A. Sol, M.M.M. Salimans, C.L. Jansen, P.M.E. Wertheim-van Dillen and J. van der Noordaa 1990 Rapid and simple method for purification of nucleic acids. Journal of Clinical Microbiology 28(3):495-503.

Brown, K.A., K. O’Donaghue and T.A. Brown 1995 DNA in cremated bones. International Journal of Osteoarchaeology 5(2):181-187.

Butler, V.L. and N.J. Bowers 1998 Ancient DNA from salmon bone: A preliminary study. Ancient Biomolecules 2:17-26.

Carter, M., I. Lilley, S. Ulm and D. Brian 1999 Mort Creek Site Complex, Curtis Coast: Site report. Queensland Archaeological Research 11:85-104.

Crockford, S. 1996 Bibliography relevant to ancient fish DNA analysis. Ichthyo-Osteo-Archaeology News 11:7-8.

David, B. 1990 How was this fish bone burnt? In S. Solomon, I. Davidson and D. Watson (eds), Problem Solving in Taphonomy: Archaeological and Palaeontological Studies from Europe, Africa and Oceania, pp.65-79. Tempus 2. St Lucia: Anthropology Museum, University of Queensland.

Dorit, R.L., W.F. Walker and R.D. Barnes 1991 Zoology. Sydney: Saunders College Publishing.

Ekanayake, S. and B.K. Hall 1988 Ultrastructure of the osteogenesis of acellular vertebral bone in the Japanese Medaka, Oryzias latipes (Teleostei, Cyprinidontidae). The American Journal of Anatomy 182:241-249.

Enlow, D.H. and S.O. Brown 1956 A comparative histological study of fossil and recent bone tissues: Part I. The Texas Journal of Science 8:405-443.

Hall, B.K. 1978 Developmental and Cellular Skeletal Biology. New York: Academic Press.

Hall, J. 1984 Exploratory excavation at Toulkerrie midden (LB:B175), Moreton Island, S.E. Queensland. Queensland Archaeological Research 1:61-84.

Hall, J., D.S. Gillieson and P. Hiscock 1988 Platypus Rockshelter (KB:A70), S.E. Queensland: Stratigraphy, chronology and site formation. Queensland Archaeological Research 5:2541.

Hall, J. and G. Bowen 1989 An excavation of a midden complex at the Toulkerrie Oysterman's lease, Moreton Island, S.E. Queensland. Queensland Archaeological Research 6:3-27.

Hlinka, V. 1997 DNA Versus Morphological Identification of Archaeological Fish Bones: Is it Feasible? Unpublished BA (Hons) thesis, Department of Anthropology and Sociology, University of Queensland, Brisbane.

Hlinka, V. 1998 Identification of modern and archaeological fish remains using genetic data. In Proceedings of the Postgraduate Research Conference. Brisbane: Department of Anthropology and Sociology, University of Queensland.

Hlinka, V. in prep. Genetic Speciation of Archaeological Fish Bones. Unpublished PhD thesis, School of Social Science, University of Queensland, Brisbane.

Hughes, D.R., J.R. Bassett and L.A. Moffat 1994 Structure and origin of the tooth pedicel (the so-called bone of attachment) and dental-ridge bone in the mandibles of the sea breams Acanthopagrus australis, Pagrus auratus and Rhabdosargus sarba (Sparidae, Perciformes, Teleostei). Anatomy and Embryology 189:51-69.

Hummel, S. and B. Herrmann 1994 General aspects of sample preparation. In B. Herrmann and S. Hummel (eds), Ancient $D N A$, pp.59-68. New York: Springer-Verlag.

Kelman, Z. and L. Moran 1996 Degradation of ancient DNA. Current Biology 6:223.
Kölliker, A. 1859 On the different types of microscopic structure of the skeleton of osseous fishes. The Proceedings of the Royal Society of London 9:656-668.

Loy, T.H. 1993 The artefact as site: An example of the biomolecular analysis of organic residues on prehistoric tools. World Archaeology 25(1):44-62.

Moss, M.L. 1961 Studies of the acellular bone of teleost fish bone I: Morphological and systemic variations. Acta Anatomica 46:343-362.

Nicholls, A.T.H. 2000 Fishing for Ancient DNA: The Development and Application of a Molecular Technique for Species Identification of Archaeological Serranid Remains. Unpublished MA thesis, Department of Anthropology, University of Auckland, Auckland, New Zealand.

Norris, W.P., W. Chavin and L.S. Lombard 1963 Studies of calcification in a marine teleost. Annals of the New York Academy of Sciences 109:312-336.

Novello, M. 1989 A Taphonomic Analysis of the Faunal Remains from Platypus Rockshelter (Site KB:A70), S.E. Queensland. Unpublished BA (Hons) thesis, Department of Anthropology and Sociology, University of Queensland, Brisbane.

Ross, A. and R. Duffy 2000 Fine mesh screening of midden material and the recovery of fish bone: The development of flotation and deflocculation techniques for an efficient and effective procedure. Geoarchaeology 15(1):21-41.

Ruben, J.A. and A. Bennett 1981 Intense exercise, bone structure and blood calcium levels in vertebrates. Nature 291:411-413.

Ruben, J.A. and A. Bennett 1987 The evolution of bone. Evolution 4:1187-1197.

Sattler, P.S. and R.D. Williams (eds) 1999 The Conservation Status of Queensland's Bioregional Ecosystems. Brisbane: Environmental Protection Agency.

Sire, J.Y., A. Huysseune and F.J. Meunier 1990 Osteocalsts in teleost fish: Light- and electron-microscopical observations. Cell Tissue Research 260:85-94.

Ulm, S. 2002 The Seven Mile Creek Mound: New evidence for mid-Holocene Aboriginal marine resource exploitation in central Queensland. Proceedings of the Royal Society of Queensland 110:111-116.

Ulm, S., M. Carter, J. Reid and I. Lilley 1999 Eurimbula Site 1, Curtis Coast: Site report. Queensland Archaeological Research 11:105-122.

Ulm, S. and J. Reid 2000 Index of dates from archaeological sites in Queensland. Queensland Archaeological Research 12:1129.

Urist, M.R. 1964 The origin of bone. Discovery 25:13-19.

Vale, D. 2002 A Report on the Analysis of Archaeological Fishbone Assemblages Retrieved from Shell Midden Sites on the Southern Curtis Coast of Central Queensland. Unpublished report to the Aboriginal and Torres Strait Islander Studies Unit, University of Queensland, Brisbane.

van Neer, W., R. Wildekamp, M. Waelkens, A. Arndt and A. Volckaert 2000 Fish as indicators of trade relationships in Roman times: The example of Sagalassos, Turkey. In M. Mashkour, A.M. Choyke, H. Buitenhuis and F. Poplin, F. (eds), Archaeozoology of the Near East IV: Proceedings of the Fourth International Symposium on the Archaeozoology of Southwestern Asia and Adjacent Areas, pp.206-215. Groningen, ARC Publication 32.

Walters, I.N. 1986 Another Kettle of Fish: The Prehistoric Moreton Bay Fishery. Unpublished PhD thesis, Department of Anthropology and Sociology, University of Queensland, Brisbane. 